\title{
Amaranthus hypochondriacus L. as a Sustainable Source of Nutrients and Bioactive Compounds for Animal Feeding
}

\author{
Marianna Oteri ${ }^{1}{ }^{\circledR}$, Fabio Gresta ${ }^{1}$, Annalisa Costale ${ }^{2}$, Vittorio Lo Presti ${ }^{1}$, Giorgia Meineri ${ }^{3}$ \\ and Biagina Chiofalo ${ }^{1, *(\mathbb{D})}$ \\ 1 Department of Veterinary Sciences, University of Messina, 98168 Messina, Italy; \\ marianna.oteri@unime.it (M.O.); fgresta@unime.it (F.G.); vittorio.lopresti@unime.it (V.L.P.) \\ 2 Department of Drug Science and Technology, University of Turin, 10125 Torino, Italy; \\ annalisa.costale@unito.it \\ 3 Department of Veterinary Sciences, University of Turin, 10095 Grugliasco, Italy; giorgia.meineri@unito.it \\ * Correspondence: biagina.chiofalo@unime.it; Tel.: +39-090-676-6833
}

Citation: Oteri, M.; Gresta, F.;

Costale, A.; Lo Presti, V.; Meineri, G.; Chiofalo, B. Amaranthus

hypochondriacus L. as a Sustainable Source of Nutrients and Bioactive Compounds for Animal Feeding. Antioxidants 2021, 10, 876. https:// doi.org/10.3390/antiox10060876

Academic Editor: Evangelos Zoidis

Received: 1 May 2021

Accepted: 27 May 2021

Published: 30 May 2021

Publisher's Note: MDPI stays neutral with regard to jurisdictional claims in published maps and institutional affiliations.

Copyright: (C) 2021 by the authors. Licensee MDPI, Basel, Switzerland. This article is an open access article distributed under the terms and conditions of the Creative Commons Attribution (CC BY) license (https:// creativecommons.org/licenses/by/ $4.0 /)$.

\begin{abstract}
With the aim to explore the use of A. hypochondriacus seeds for animal feeding, the agronomic traits, nutrients, and bioactive compounds of four accessions with different origin (India, Nebraska, Iowa, and Pennsylvania) grown in a Mediterranean environment were studied. Proximate composition was determined using the official methods of analyses, fatty acid profile by gas chromatography, total phenolic content (TPC) and the scavenging activity (DPPH ${ }^{\bullet}$ and $\mathrm{ABTS}^{\bullet+}$ ) by colorimetric method. A one-way ANOVA model was performed to determine the differences between accessions. The four A. hypochondriacus accessions showed interesting seed yield results. No significant differences were observed for crude protein and crude fiber; the oil content showed the significant highest values in the seeds from Nebraska and Pennsylvania, but their nutritional characteristics were significantly different. The accession from Nebraska showed the highest oleic and linoleic acid levels, the highest values of polyunsaturated fatty acids, the best atherogenic and thrombogenic indices and hypocholesterolemic/hypercholesterolaemic ratio, and the highest TPC content. The accession from Pennsylvania showed the highest antioxidant activity and lowest peroxidation index. On the whole, A. hypochondriacus seeds can be used as pseudo-cereal to balance the animal diet and the accession should be chosen according to the different metabolic pathways of unsaturated fatty acids in ruminant and monogastric animals.
\end{abstract}

Keywords: amaranth; germplasm; agronomic traits; proximate composition; fatty acids; nutritional indices; phenolic compounds; antioxidant activity; feedstuff

\section{Introduction}

Amaranthus genus belongs to the Amaranthaceae family and is considered an invasive fast-growing species with a high capability of colonization due to the strategic adaptive seed germination [1,2]. Anyway, it is also considered a pseudo-cereal [3] and the three well-known main species are Amaranthus hypochondriacus, Amaranthus cruentus, and Amaranthus caudatus. They grow in temperate and tropical regions and have some agronomic advantages, namely, rapid growth, the ability to adapt to unfavorable growing conditions, and tolerance to high temperatures [4].

The recent interest for this plant genus is due to its high nutritional value of seed. In fact, Amaranthus is a promising plant that may provide proteins of high quality, high levels of unsaturated fatty acids, and various other valuable constituents [5]. Its seeds exhibit a valuable combination of nutritional traits, showing a higher protein and oil content compared to the conventional cereals such as corn [6] or sorghum [7] and a fatty acid profile (i.e., oleic acid) with beneficial effects for cardiovascular diseases, hypertension, hypercholesterolemia, diabetes, cancer, and inflammations, and contribute to immunity strengthening $[4,8]$. 
Furthermore, amaranth contains interesting compound deriving from the secondary metabolism, which shows health beneficial effects in human and animal diet [9]. Over the past fifteen years, some research have been carried out on the content of phenolic compounds of amaranth seeds [10] and on their functional and bioactive properties [11-14].

Seven different phenolic acids in Amaranthus cruentus seed have been identified: caffeic, ferulic, sinapic, $p$-coumaric, cinnamic, p-hydroxybenzoic, and vanillic acids [15]. The occurrence of ferulic acid in amaranth seeds might be considered as beneficial to health from the dietary point of view, because ferulic acid is considered a cholesterol-lowering, anti-thrombosis, anti-inflammatory, and anti-cancer factor [16]. The natural functions of hydroxycinnamic acids seem related to stabilization and protection of grain lipids [17]. The presence of caffeic, protocatechuic, and ferulic acids was also confirmed in Amaranthus hybridus seeds [18].

To our knowledge, no data are reported on the phenolic profile of A. hypocondriacus seed. However, information on the phenolic acid profile is essential to assess the relevance of $A$. hypochondriacus as potential source of dietary antioxidants. In fact, amaranth is becoming more and more important as animal feed and it could become a possible substitute for traditional cereals [19].

The inclusion of amaranth grain in feedstuff for many animals including cattle, chickens, pigs, and rabbits depends on its high nutritive and functional values as well as on its high digestibility and/or degradability [20]. Studies showed that the amaranth grain could be considered a valuable feed for rabbits [21], pigs [22], poultry [23], especially in the tropical and sub-tropical regions. The results on in vivo performance varied considerably within-species due to age, feed formulation, and processing method used [24-30]. In a previous paper [31], Gresta et al. underlined that amaranth can be considered an alternative livestock feed to oilseed and to traditional cereal grains in the Mediterranean area. Among Amaranthus spp., A. hypochondriacus, is known for its ability to tolerate stressful conditions and produce highly nutritious seeds with the highest oil and the lowest fiber levels [32]. In fact, this species possesses a considerable protein content with an optimal amino acid balance, and an outstanding profile of the crude fat [32], due to the high content of bioactive compounds such as polyunsaturated fatty acids, both of the n3- and n6-PUFA series, which reduce the incidence of cardiovascular diseases [33]. Akin-Idowu et al. [34] comparing the phenolic compounds and antioxidant activity of five grain amaranth species (A. caudatus, A. cruentus, A. Hybrid, A. hypochondriacus and A. hybridus) observed that A. hypochondriacus and $A$. hybridus had the highest value together with the highest DPPH activity. Barba de La Rosa et al. [35] reported that polyphenols of $A$. hypochondriacus in which sugar groups are beta-linked, are easily degraded in the intestine of humans and animals underlining their potential impact on its nutraceutical property. As far as A. hypochondriacus grain utilization in animal feeding is concerned, different studies have been performed [36-39] without adverse effects on performance.

With this in mind, the aim of this study is to characterize the agronomic characteristics, oil content, fatty profile, antioxidant activity, and total phenolic content of four accessions of A. hypochondriacus seeds with different origin (from India, Nebraska, Iowa and Pennsylvania), grown in the same area, in order to increase the knowledge of this plant as a source of nutrients and bioactive compounds (essential fatty acids and polyphenols) for animal feeding.

\section{Materials and Methods}

\subsection{Field Experiment and Plant Material}

The trial was performed in 2014 in Bovalino (RC) $\left(20 \mathrm{~m}\right.$ a.s.l. $\left.38^{\circ} 08^{\prime} \mathrm{N}, 16^{\circ} 10^{\prime} \mathrm{E}\right)$ in the southern part of Calabria (Italy). Four accessions of Amaranthus hypochondriacus obtained from the USDA (Washington, DC, USA) seed bank were studied in a sandy-loam soil. 
Seeds were previously grown in a nursery and then transplanted in the field. Sowing was performed manually on 21st March inside a nursery in expanded polystyrene trays and kept at $26{ }^{\circ} \mathrm{C}$ and $85 \%( \pm 5 \%) \mathrm{RH}$. Four days later the plants with four true leaves were transplanted in the field with a plant density of 10 plants per $\mathrm{m}^{2}(1.0 \times 0.10 \mathrm{~m})$. In a randomized block design three time replicated with plots of $9 \mathrm{~m}^{2}(3 \times 3 \mathrm{~m})$ was adopted. Seed density and plot dimensions were forced by the exiguous amount of seed received from the seed bank.

The soil was shallow plowed and fertilized with $40 \mathrm{~kg} / \mathrm{ha}$ of $\mathrm{N}, 80 \mathrm{~kg} / \mathrm{ha}$ of $\mathrm{P}_{2} \mathrm{O}_{5}$, and $60 \mathrm{~kg} / \mathrm{ha}$ of $\mathrm{K}_{2} \mathrm{O}$ before transplant. Just before anthesis, a further supply of $80 \mathrm{~kg} / \mathrm{ha}$ of $\mathrm{N}$ as ammonium nitrate was broadcasted. Plants were irrigated with a total volume of $3200 \mathrm{~m}^{3}$ / ha supplied with a drip system. Harvest was staggered from 5 to 11 July in relation to the degree of maturation of the different accessions, just before seed shattering. Weeds were managed by hand during the trial and seeds were finally threshed with a laboratory thresher.

During the trial, temperatures and rainfalls were recorded by a data logger placed next to the experimental field.

The average temperature ranged from $17.7^{\circ} \mathrm{C}$ at sowing to $25.2^{\circ} \mathrm{C}$ at harvest. The lowest temperature was recorded at the end of April $\left(14.6^{\circ} \mathrm{C}\right)$, while the highest was recorded at the end of June $\left(30.1^{\circ} \mathrm{C}\right)$. As usually happens in spring-summer period in the Mediterranean areas, rainfall was inconsistent $(26.4 \mathrm{~mm})$.

\subsection{Solvents and Chemicals}

Sulfuric acid $\left(\mathrm{H}_{2} \mathrm{SO}_{4}\right), 72 \%$ and 95-98\%; hydrogen peroxide solution $\left(\mathrm{H}_{2} \mathrm{O}_{2}\right), 30 \%$; boric acid $\left(\mathrm{H}_{3} \mathrm{BO}_{3}\right) 1 \%$ with indicator; sodium hydroxide $(\mathrm{NaOH}), 40 \%$; anhydrous $\mathrm{NaOH}$ in pellets and hydrochloric acid $(\mathrm{HCl}), 0.1 \mathrm{~N}$ were all purchased from Carlo Erba (Carlo Erba Reagents S.r.l., Milano, Italy); catalysts Kjeltabs $\mathrm{Cu} / 3,5$ were obtained from the FOSS (FOSS, Padua, Italy). $\mathrm{HCl} 37 \%$, petroleum ether (bp: boiling point $40-60{ }^{\circ} \mathrm{C}$ ), methanol, and $n$-hexane were provided by Honeywell Fluka (Fisher Scientific Italia, Milan, Italy) and N-free filter paper (Cytiva Carta B-2 Parchment, Parchment Paper, B-2 grade) from Fisher Scientific Italia (Milan, Italy). Supelco 37 Component FAME Mix, Folin-Ciocalteu phenol reagent (FCR), gallic acid, 2,2-diphenyl-1-picrylhydrazyl (DPPH ${ }^{\bullet}$ ), 2,2-azinobis (3-ethyl-benzothiazoline-6-sulfonic acid) (ABTS), potassium persulphate, 6-hydroxy-2,5,7,8tetramethy-chromam-2-carboxylic acid (Trolox), and sodium carbonate were obtained from Sigma-Aldrich (Merck KGaA, Darmstadt, Germany). Solvents and chemicals were all of analytical grade.

\subsection{Chemical Analysis}

Determination of moisture and ash content in amaranth seeds was performed by using an automated thermogravimetric analyzer (TGA-701), purchased from LECO Corporation (Milano, Italy), measuring the material weight loss as a function of temperature in a controlled environment until constant weight. Moisture measurement was determined on

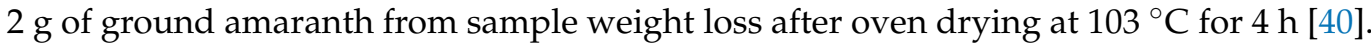
Ash content determination was performed according to the official method calculating the weight remaining after heating $2 \mathrm{~g}$ of sample at $600{ }^{\circ} \mathrm{C}$ for $2 \mathrm{~h} \mathrm{[41].}$

Nitrogen content was determined with a Kjeltec system (Foss) using Kjeldahl procedure [41]. The method consisted in a digestion of $1 \mathrm{~g}$ of ground sample with concentrated sulfuric acid (95-98\%) and hydrogen peroxide solution (30\%), using two catalyst tablets, for $1 \mathrm{~h}$ at $420^{\circ} \mathrm{C}$. After cooling at room temperature, the mineralized sample was diluted with $\mathrm{H}_{2} \mathrm{O}$ in the automatic apparatus and neutralized using sodium hydroxide (40\%). Subsequently, the solution was distilled using boric acid 1\% with indicator and titrated using $\mathrm{HCl} 0.1 \mathrm{~N}$. The residue of analysis obtained as Kjeldahl nitrogen content was converted to percent of crude protein using a conversion factor of 6.25 [41]. Determination of total lipid content of the four accessions of $A$. hypochondriacus seeds was carried out by using 
Soxtec $^{\mathrm{TM}} 8000$ Extraction system and Hydrotec ${ }^{\mathrm{TM}} 8000$ Hydrolysis System purchased from FOSS (Padua, Italy) [42].

Lipid extraction of each accession of $A$. hypochondriacus was performed using petroleum ether (bp, $40-60^{\circ} \mathrm{C}$ ) for $6 \mathrm{~h}$ by the Soxtec system after acid hydrolysis in Hydrotec system with $3 \mathrm{~N} \mathrm{HCl}$. All extracts were dried in a ventilated oven until constant weight and the total lipid extraction yield were determined gravimetrically.

Crude fiber contents were determined according to the official method [41]. Initially, $2 \mathrm{~g}$ of sample was degreased three times with petroleum ether for a cold extraction, and pre-heated $\mathrm{H}_{2} \mathrm{SO}_{4} 1.25 \%$ was added until a uniform boil was attained and was let to boil for $30 \mathrm{~min}$. At this point, the sample was filtered and washed with warm water for three times. Then, pre-heated $\mathrm{NaOH} 1.25 \%$ was added and let to boil for $30 \mathrm{~min}$. At this point, the sample was washed with warm water and $\mathrm{H}_{2} \mathrm{SO}_{4} 1.25 \%$ and filtered. The crucible containing the sample was dried for $2 \mathrm{~h}$ at $130{ }^{\circ} \mathrm{C}$ and weighed. Furthermore, the sample was incinerated for $2 \mathrm{~h}$ at $550{ }^{\circ} \mathrm{C}$, cooled in a desiccator and weighed. The determination of crude fiber was gravimetrically carried out.

Each accession of $A$. hypochondriacus samples was analyzed in triplicate.

\subsection{Fatty Acids Analysis and Nutritional Indices}

Fatty acid (FA) profiles evaluation, as fatty acid methyl esters (FAMEs), was performed after a direct trans-methylation treating the obtained lipid extracts with $2 \mathrm{~mL}$ of a sulfuric acid: methanol $(1: 9, v / v)$ mixture for $1 \mathrm{~h}$ at $100{ }^{\circ} \mathrm{C}$ [43]. After cooling to room temperature, the mixture was treated with $1 \mathrm{~mL}$ of $\mathrm{n}$-hexane for the extraction of FAMEs. The supernatant, containing the methyl esters, was filtered using nylon filters $0.45 \mu \mathrm{m}$, transferred into a vial, and injected into a gas chromatographic (GC) system equipped with flame ionization detector (FID) for quali-quantitative FAMEs analysis, according to a Gresta et al. [31].

Chromatographic separations of FAMEs were carried out by means of a GC-FID (TRACE 1310) system equipped with an AI 1310 Autoinjector/AS 1310 Autosampler both from Thermo Fisher Scientific (Milan, Italy), and an Omegawax 250 (Supelco, Bellefonte, PA, USA), $30 \mathrm{~m} \times 0.25 \mathrm{~mm}$, $(\mathrm{L} \times$ I.D.), $0.25 \mu \mathrm{m}$ film thickness capillary polar column. GC conditions were set as follows: injector and detector temperature, $250{ }^{\circ} \mathrm{C}$; injection volume, $0.5 \mu \mathrm{L}$; split ratio, 1:50; oven temperature program: $100{ }^{\circ} \mathrm{C}$ for $5 \mathrm{~min}$, $100-240{ }^{\circ} \mathrm{C}$ at $4{ }^{\circ} \mathrm{C} / \mathrm{min}$ in $35 \mathrm{~min}$, held at $240{ }^{\circ} \mathrm{C}$ for $20 \mathrm{~min}$; carrier gas (He) at a flow rate of $1 \mathrm{~mL} / \mathrm{min}$; make-up gas $\left(\mathrm{N}_{2}\right)$ flow, $40 \mathrm{~mL} / \mathrm{min} ; \mathrm{H}_{2}$ flow, $35 \mathrm{~mL} / \mathrm{min}$; air flow, $350 \mathrm{~mL} / \mathrm{min}$. Data acquisition was processed through the Chromeleon ${ }^{\mathrm{TM}}$ Data System (Thermo Fisher Scientific, Milan, Italy) software (Version 7.2.9). In order to identify the individual compounds, a standard solution of 37 FAMEs $\left(\mathrm{C}_{4}-\mathrm{C}_{24}\right)$ was analyzed under the same analytical conditions of the unknown samples; chromatogram peaks were identified by comparing the relative retention times of FAMEs in the samples with the standard solution ones. The concentrations of the single fatty acids were expressed as $\mathrm{g} / 100 \mathrm{~g}$, considering $100 \mathrm{~g}$ as the summation of the areas of all the identified FAMEs.

Nutritional indices were calculated from the identified FAs using the equations proposed by Ulbricht and Southgate [33] for atherogenicity (AI) and thrombogenicity (TI) indices, while Santos-Silva et al. equation [44] was used for the calculation of the hypocholaesterolemic and hypercholaesterolemic ratio $(\mathrm{H} / \mathrm{H})$. Indices were determinated as shown in the equations below:

$$
\begin{gathered}
\mathrm{AI}=[\mathrm{C} 12: 0+(4 \times \mathrm{C} 14: 0)+\mathrm{C} 16: 0] /(\Sigma \mathrm{n} 6-\mathrm{PUFA}+\Sigma \mathrm{n} 3-\mathrm{PUFA}+\Sigma \mathrm{MUFA}) \\
\mathrm{TI}=(\mathrm{C} 14: 0+\mathrm{C} 16: 0+\mathrm{C} 18: 0) /[(0.5 \times \Sigma \mathrm{MUFA})+(0.5 \times \Sigma \mathrm{n} 6-\mathrm{PUFA}) \\
+(3 \times \Sigma \mathrm{n} 3-\mathrm{PUFA})+(\Sigma \mathrm{n} 3-\mathrm{PUFA} / \Sigma \mathrm{n} 6-\mathrm{PUFA})] \\
\mathrm{H} / \mathrm{H}=(\mathrm{C} 18: 1 \mathrm{n} 9+\mathrm{C} 18: 2 \mathrm{n} 6+\mathrm{C} 20: 4 \mathrm{n} 6+\mathrm{C} 18: 3 \mathrm{n} 3+\mathrm{C} 20: 5 \mathrm{n} 3+\mathrm{C} 22: 5 \mathrm{n} 3+\mathrm{C} 22: 6 \mathrm{n} 3) / \\
(\mathrm{C} 14: 0+\mathrm{C} 16: 0)
\end{gathered}
$$


Furthermore, peroxidation index (PI), which expresses a measure of peroxidation susceptibility and peroxidative lipid damage for a particular phospholipid membrane, was calculated, taking into account the fatty acids composition and using the formula shown below [45]:

$\mathrm{PI}=(\%$ dienoic $\times 1)+(\%$ trienoic $\times 2)+(\%$ tetraenoic $\times 3)+(\%$ pentaenoic $\times 4)+(\%$ hexaenoic $\times 5)$

\subsection{Total Phenolic and Antioxidant Activity Analyses}

Determination of total phenolic content (TPC) and antioxidant capacity was carried out on milled A. hypochondriacus seeds.

According to López-Mejía et al.'s method [46], $10 \mathrm{~g}$ of sample was treated with $150 \mathrm{~mL}$ of methanol and extracted in darkness for $15 \mathrm{~h}$ at room temperature. The sample, once extracted, was filtered and washed, three times, with methanol; at last, the solvent was removed using a rotary evaporator. Extraction yields (\%) were calculated gravimetrically considering seeds weight and dry extracts.

Total phenolic content (TPC) was determinate by the Folin-Ciocalteu colorimetric method [10] as follows: $250 \mu \mathrm{L}$ of methanolic solution of extract $(5 \mathrm{mg} / \mathrm{mL}), 250 \mu \mathrm{L}$ of FCR, $500 \mu \mathrm{L}$ of $10 \%$ sodium carbonate solution, and $4 \mathrm{~mL}$ of water, were mixed. The mixture was incubated for $25 \mathrm{~min}$ in a dark environment at room temperature, centrifuged $5 \mathrm{~min}$ at $5000 \mathrm{rpm}$, and the absorbance was measured at a wavelength of $725 \mathrm{~nm}$. The results were expressed as $\mathrm{mg}$ of gallic acid equivalents (GAE, $\mathrm{mg} / \mathrm{g}$ ) per $\mathrm{g}$ of sample. Each determination was performed in triplicate. Methanol extracts of polyphenols were analyzed for their antioxidant capacity by $\mathrm{DPPH}^{\bullet}$ and $\mathrm{ABTS}^{\bullet+}$ assays. The $\mathrm{DPPH}^{\bullet}$ scavenging activity was evaluated according to the procedure described by Brand-Williams et al. [47]. The DPPH ${ }^{\bullet}$ radical is stable in methanol solution; extracts of antioxidants scavenge the $\mathrm{DPPH}^{\bullet}$, and the reduction of $\mathrm{DPPH}^{\bullet}$ is monitored by the decrease of the absorbance at wavelength $517 \mathrm{~nm}$. An aliquot of methanol solution $(0.1 \mathrm{~mL})$ containing different concentrations (from $2-10 \mathrm{mg} / \mathrm{mL}$ of initial sample), was added to $0.25 \mathrm{~mL}$ of $1 \mathrm{mM}$ DPPH and $2 \mathrm{~mL}$ of methanol, mixed and the absorbance was measured after $20 \mathrm{~min}$ $(\lambda=517 \mathrm{~nm}$ ) by a Cary $60 \mathrm{UV}$-Vis spectrophotometer (Agilent Technologies, Santa Clara, CA, USA). Data were used to determine the quantity $(\mu \mathrm{g})$ of polyphenols needed to scavenge $50 \%$ of the $\mathrm{DPPH}^{\bullet}$ (EC50). Then, EC50 values, considered as dried extract concentration (mg/mL solution) needed to scavenge the $50 \%$ of initial $\mathrm{DPPH}^{\bullet}$, were evaluated. The Trolox equivalent antioxidant capacity (TEAC) was determined according to the assay reported by Karamać et al. [10]. Total of $20 \mu \mathrm{L}$ of methanolic solution of extracts $(20 \mathrm{mg} / \mathrm{mL})$ or methanolic Trolox standard solution was mixed with $2 \mathrm{~mL} \mathrm{ABTS}{ }^{\bullet+}$ diammonium salt radical cation, vortexed and heated at $30^{\circ} \mathrm{C}$. The absorbance was read at $\lambda=734 \mathrm{~nm}$ by a Cary 60 UV-Vis spectrophotometer (Agilent Technologies, Santa Clara, CA, USA) within $6 \mathrm{~min}$. The final results were expressed as $\mu \mathrm{mol} \mathrm{TE}$ (Trolox equivalents) $/ \mathrm{g}$ of seed.

\subsection{Statistical Evaluation}

A one-way ANOVA model was adopted to analyze the data. When significative difference was detected among accessions, Tukey's (HSD) test was applied, using DSAASTAT v. 1.1 software [48]. To ensure normality, percentage values were previously arcsin square root transformed; in tables, percentage data were reported.

\section{Results}

The four accessions of A. hypochondriacus from India, Nebraska, Iowa, and Pennsylvania are listed in Table 1 with plant inventory code. 
Table 1. Four studied Amaranthus hypochondriacus accessions.

\begin{tabular}{cccc}
\hline Accession & Origin & $\begin{array}{c}\text { Seed Weight per Plant } \\
(\mathbf{g})\end{array}$ & $\begin{array}{c}\text { 1000 Seed Weight } \\
(\mathbf{g})\end{array}$ \\
\hline PI 477915 & India & $28.0^{\mathrm{b}}$ & $0.85^{\mathrm{a}}$ \\
PI 558499 & USA, Nebraska & $43.3^{\mathrm{a}}$ & $0.77^{\mathrm{ab}}$ \\
PI 568125 & USA, Iowa & $27.4^{\mathrm{b}}$ & $0.84^{\mathrm{a}}$ \\
PI 572256 & USA, Pennsylvania & $43.7^{\mathrm{a}}$ & $0.68^{\mathrm{b}}$ \\
\hline PI = plant inventory. & &
\end{tabular}

\subsection{Productive Traits}

Accessions from Nebraska and Pennsylvania showed the highest seed weight per plant (43.5 g, on average) significantly higher than accessions from India and Iowa ( $27.7 \mathrm{~g}$, on average) (Table 1). On the other hand seed weight was higher in the accessions from India and Iowa ( $0.85 \mathrm{~g}$ for 1000 seeds, on average), even though not significatively different from Nebraska $(0.77 \mathrm{~g})$.

\subsection{Chemical Composition}

Table 2 shows the mean values of the chemical composition in the four studied accessions of amaranth seed. Crude protein and crude fiber showed a similar $(p>0.05)$ content among all the A. hypochondriacus accessions. Significant differences between Amaranth accessions were also observed for the oil content and ash (Table 2). Nebraska (USA) and Pennsylvania (USA) showed a significantly higher $(p<0.05)$ oil content compared to India. The ash content was significantly $(p<0.05)$ higher in the accessions from Nebraska (USA) and Iowa (USA) than that from Pennsylvania (USA).

Table 2. Mean values of three replications of the chemical composition (g/100 on dry matter) in the four accessions of $A$. hypochondriacus seed.

\begin{tabular}{ccccccc}
\hline Accession & Origin & Moisture & Crude Protein & Oil & Crude Fiber & Ash \\
\hline PI 477915 & India & 10.40 & 18.30 & $5.39^{\mathrm{b}}$ & 4.84 & $3.36^{\mathrm{ab}}$ \\
PI 558499 & USA, Nebraska & 10.20 & 17.60 & $7.23^{\mathrm{a}}$ & 5.42 & $3.53^{\mathrm{a}}$ \\
PI 568125 & USA, Iowa & 10.30 & 17.30 & $6.00^{\mathrm{ab}}$ & 5.85 & $3.54^{\mathrm{a}}$ \\
PI 572256 & USA, Pennsylvania & 10.20 & 17.70 & $6.87^{\mathrm{a}}$ & 5.77 & $3.26^{\mathrm{b}}$ \\
\hline Average & & 10.3 & 17.73 & 6.37 & 5.47 & 3.42 \\
\hline
\end{tabular}

PI = plant inventory. Mean values with different letters $(\mathrm{a}-\mathrm{c})$ within the same column differ significantly $(p<0.05)$.

\subsection{Fatty Acids, Total Phenolic Contents, and Antioxidant Activity}

Fatty acid composition in the four amaranth seeds is presented in Table 3. Linoleic (C18:2n6), palmitic (C16:0), and oleic (C18:1n9) acids were the dominant fatty acids in all samples. The linoleic acid (C18:2n6) exhibited the significantly $(p<0.05)$ highest level in the accessions from India PI 558499, Nebraska, and Iowa. The palmitic (C16:0) showed a significantly $(p<0.05)$ higher value in the accession from Pennsylvania than those from Nebraska, Iowa, and India. The oleic acid (C18:1n9) showed a significantly $(p<0.05)$ higher value in the accession from Nebraska than those of Pennsylvania and India, while accession from Iowa showed a similar content among the four accessions. Pennsylvania showed the significantly $(p<0.05)$ highest value of stearic acid (C18:0). The myristic (C14:0), palmitoleic (C16:1), heptadecanoic (C17:0), cis-11-octadecenoic acid (C18:1n7) an isomer of oleic acid, the alpha-linolenic (C18:3n3), arachic (C20:0), and docosanoic (C22:0) acids were lower than $2 \%$ in all amaranth accessions (Table 2 ). 
Table 4 covers the fatty acid classes, the fatty acid ratios, and the quality indices, $\mathrm{AI}$ and TI. The accession from Nebraska showed the significantly $(p<0.05)$ lowest value of SFAs; MUFAs did not show any statistical differences $(p>0.05)$ among the studied accessions, while the accession from Pennsylvania showed the significantly $(p<0.05)$ lowest value of PUFAs and, in particular, n6-PUFAs, and the significantly $(p<0.05)$ highest value of SFAs (Table 4). Consequently, the SFA/UFA ratio showed the significantly $(p<0.05)$ highest value in the accession from Pennsylvania and the lowest in that from Nebraska (Table 4). As regards the nutritional indices, strictly related to the fatty acid profile, the AI, TI, and $\mathrm{H} / \mathrm{H}$ showed the significantly $(p<0.05)$ best values in the accession from Nebraska and the worst values in that from Pennsylvania, and the PI, showed the significantly $(p<0.05)$ lowest value in the accession from Pennsylvania (Table 4).

Table 5 showed the total phenolic content (TPC) and the antioxidant power (DPPH ${ }^{\bullet}$ and $\mathrm{ABTS}^{\bullet+}$ ) in the four different accessions of $A$. hypochondriacus. The accession from Nebraska showed the significantly $(p<0.05)$ highest TPC content whereas, the accession from Iowa showed the significantly $(p<0.05)$ lowest value.

As regards the antioxidant power, the $\mathrm{DPPH}^{\bullet}$ values showed the lowest $(p<0.05)$ level in the accession from Pennsylvania and the highest $(p<0.05)$ value in that from Iowa. Intermediate significantly different $(p<0.05)$ values were observed for the accessions from Nebraska and India. The DPPH ${ }^{\bullet}$, in the different accessions of $A$. hypochondriacus varied significantly $(p<0.05)$ in this order: Iowa $>$ Nebraska $>$ India $>$ Pennsylvania (Table 5). Accession from Iowa showed a high $\mathrm{DPPH}^{\bullet}$ value (low antioxidant activity) in relation to the high content of PUFAs which are unstable to oxidation (Table 4). The accession from Pennsylvania, maintains a low $\mathrm{DPPH}^{\bullet}$ value (high antioxidant activity) in relation to the high content of SFAs which are stable to oxidation (Table 4). From a health point of view, the accession from Nebraska represents the best accession showing the highest content of polyphenols, an intermediate $\mathrm{DPPH}^{\bullet}$ value, the lowest SFA, and the highest PUFA content (Table 4); in this case, the observed TPC value can counteract the oxidation of the PUFA present in the plant. The $\mathrm{ABTS}^{\bullet+}$ radical-scavenging activity showed a significantly $(p<0.05)$ higher value (high antioxidant activity) in the accession from Pennsylvania than those determined in the other accession which ranged from 1.75 to $2.22 \mu \mathrm{mol} \mathrm{TE} / \mathrm{g}$ seeds, according to the highest SFA content in this accession, as stated above for the $\mathrm{DPPH}^{\bullet}$ value.

Table 3. Mean values of three replications of the fatty acid profile $(\mathrm{g} / 100 \mathrm{~g}){ }^{*}$ in the four accessions of A. hypochondriacus seed.

\begin{tabular}{|c|c|c|c|c|c|c|c|c|c|c|c|c|c|}
\hline Accession & Origin & C14:0 & C16:0 & C16:1 & C17:0 & C18:0 & C18:1n9 & C18:1n7 & C18:2n6 & C18:3n3 & C20:0 & C22:0 & Other \\
\hline PI 477915 & India & $0.75^{b}$ & $27.00^{b}$ & 0.23 & $0.41^{\mathrm{b}}$ & $5.89^{b}$ & $26.40^{\mathrm{b}}$ & 1.42 & $34.00^{\mathrm{a}}$ & $0.62^{a}$ & $0.85^{\mathrm{b}}$ & $0.42^{b}$ & $1.96^{\mathrm{b}}$ \\
\hline PI 558499 & USA, Nebraska & $0.67^{c}$ & $25.30^{c}$ & 0.25 & $0.41^{b}$ & $5.03^{\mathrm{d}}$ & $29.20^{a}$ & 1.41 & $34.30^{\mathrm{a}}$ & $0.50^{b c}$ & $0.75^{\mathrm{b}}$ & $0.36^{\mathrm{c}}$ & $1.77^{b c}$ \\
\hline PI 568125 & USA, Iowa & $0.59^{d}$ & $26.20^{b c}$ & 0.29 & $0.36^{c}$ & $5.38^{\mathrm{c}}$ & $28.40^{\mathrm{ab}}$ & 1.43 & $33.80^{\mathrm{a}}$ & $0.54^{b}$ & $0.82^{b}$ & $0.40^{\mathrm{b}}$ & $1.70^{\mathrm{c}}$ \\
\hline PI 572256 & USA, Pennsylvania & $0.83^{\mathrm{a}}$ & $29.00^{\mathrm{a}}$ & 0.44 & $0.51^{\mathrm{a}}$ & $6.39^{a}$ & $26.60^{b}$ & 1.43 & $30.70^{\mathrm{b}}$ & $0.44^{\mathrm{c}}$ & $1.03^{a}$ & $0.49^{\mathrm{a}}$ & $2.20^{\mathrm{a}}$ \\
\hline Average & & 0.71 & 26.88 & 0.30 & 0.42 & 5.67 & 27.65 & 1.42 & 33.20 & 0.53 & 0.86 & 0.42 & 1.91 \\
\hline
\end{tabular}

PI = plant inventory. Mean values with different letters $(\mathrm{a}, \mathrm{b}, \mathrm{c}, \mathrm{d}, \mathrm{ab}, \mathrm{bc})$ within the same column differ significantly $(p<0.05) .{ }^{*}$ The concentration of individual fatty acids was expressed per total fatty acid methyl esters identified. C14:0 = myristic acid; $\mathrm{C} 16: 0=$ palmitic acid; $\mathrm{C} 16: 1$ = palmitoleic acid; $\mathrm{C} 17: 0=$ heptadecanoic acid; $\mathrm{C} 18: 0=$ stearic acid; $\mathrm{C} 18: 1 \mathrm{n} 9=$ oleic acid; $\mathrm{C} 18: 1 \mathrm{n} 7=$ cis-vaccenic acid; $\mathrm{C} 18: 2 \mathrm{n} 6=$ linoleic acid; $\mathrm{C} 18: 3 \mathrm{n} 3=\alpha$-linolenic acid; $\mathrm{C} 20: 0=$ arachidic acid; $\mathrm{C} 22: 0=$ behenic acid . 
Table 4. Mean values of three replications of fatty acid classes $(\mathrm{g} / 100 \mathrm{~g}) *$, ratios and quality indices in the four accessions of A. hypochondriacus seed.

\begin{tabular}{|c|c|c|c|c|c|c|c|c|c|c|c|}
\hline Accession & Origin & SFA & MUFA & PUFA & SFA/UFA & n3 & n6 & AI & TI & $\mathrm{H} / \mathrm{H}$ & PI \\
\hline PI 477915 & India & $35.40^{\mathrm{b}}$ & 28.10 & $34.60^{a}$ & $0.56^{\mathrm{b}}$ & $0.62^{a}$ & $34.00^{\mathrm{a}}$ & $0.48^{\mathrm{b}}$ & $1.02^{b}$ & $2.20^{\mathrm{b}}$ & $35.20^{\mathrm{a}}$ \\
\hline PI 558499 & USA, Nebraska & $32.50^{c}$ & 30.90 & $34.80^{\mathrm{a}}$ & $0.50^{\mathrm{c}}$ & $0.50^{b c}$ & $34.30^{\mathrm{a}}$ & $0.43^{c}$ & $0.91^{\mathrm{c}}$ & $2.47^{\mathrm{a}}$ & $35.30^{\mathrm{a}}$ \\
\hline PI 568125 & USA, Iowa & $33.80^{b c}$ & 30.10 & $34.40^{\mathrm{a}}$ & $0.52^{b c}$ & $0.54^{\mathrm{b}}$ & $33.80^{\mathrm{a}}$ & $0.44^{b c}$ & $0.96^{\mathrm{bc}}$ & $2.34^{\mathrm{ab}}$ & $34.90^{\mathrm{a}}$ \\
\hline PI 572256 & USA, Pennsylvania & $38.20^{a}$ & 28.50 & $31.10^{\mathrm{b}}$ & $0.64^{a}$ & $0.44^{c}$ & $30.70^{\mathrm{b}}$ & $0.54^{\mathrm{a}}$ & $1.17^{\mathrm{a}}$ & $1.94^{c}$ & $31.60^{\mathrm{b}}$ \\
\hline Average & & 35.00 & 29.40 & 33.73 & 0.56 & 0.53 & 33.20 & 0.47 & 1.02 & 2.24 & 34.25 \\
\hline
\end{tabular}

PI = plant inventory. Mean values with different letters $(\mathrm{a}, \mathrm{b}, \mathrm{c}, \mathrm{ab}, \mathrm{bc})$ within the same column differ significantly $(p<0.05) .{ }^{*}$ The concentration of fatty acid classes was expressed per total fatty acid methyl esters identified. SFA = saturated fatty acids; MUFA = monounsaturated fatty acids; PUFA = polyunsaturated fatty acids; n3 = n3-polyunsaturated fatty acids; n6 = n6-polyunsaturated fatty acids; $\mathrm{SFA} / \mathrm{UFA}=$ saturated/unsaturated fatty acid ratio; $\mathrm{AI}=$ atherogenic index; $\mathrm{TI}=$ thrombogenic index; $\mathrm{H} / \mathrm{H}=$ hypo-/hypercholesterolaemic ratio; $\mathrm{PI}=$ peroxidation index.

Table 5. Mean values of three replications of antioxidant properties in the four accessions of A. hypochondriacus seed.

\begin{tabular}{ccccc}
\hline Accession & Origin & TPC & DPPH $^{\bullet}$ & ABTS $^{\bullet+}$ \\
\hline PI 477915 & India & $0.31^{\mathrm{b}}$ & $0.42^{\mathrm{c}}$ & $1.84^{\mathrm{b}}$ \\
PI 558499 & USA, Nebraska & $0.40^{\mathrm{a}}$ & $0.45^{\mathrm{b}}$ & $2.22^{\mathrm{b}}$ \\
PI 568125 & USA, Iowa & $0.24^{\mathrm{c}}$ & $0.54^{\mathrm{a}}$ & $1.75^{\mathrm{b}}$ \\
PI 572256 & USA, Pennsylvania & $0.30^{\mathrm{b}}$ & $0.34^{\mathrm{d}}$ & $3.08^{\mathrm{a}}$ \\
\hline Average & & 0.31 & 0.44 & 2.22
\end{tabular}

PI = plant inventory. Mean values with different letters (a, b, c, d) within the same column differ significantly $(p<0.05)$. TPC $=$ total phenolic content expressed as gallic acid equivalents (GAE mg/g seeds); $\mathrm{DPPH}^{\bullet}$ scavenging activity expressed as E C50 (concentration of dried extract $\mathrm{mg} / \mathrm{mL}$ solution); $\mathrm{ABTS}^{\bullet+}$ scavenging activity expressed as $\mu \mathrm{mol}$ TE (Trolox equivalents)/g seeds).

\section{Discussion}

Interesting seed yield was recorded in our trial. Compared to the literature data, in our trial seed yield was higher than that reported on the same species by El Gendy et al. [5] and by Pulvento et al. [49]. Our data resulted in agreement to the result obtained by Gimplinger et al. [42] with the same plant density. The 1000 seed weight is also in agreement with Gimplinger et al. who found a 1000 seed weight ranging from 0.55 to $1.04 \mathrm{~g}$ [50]. Seed yield seems to be inversely related to the 1000 seed weight. In fact, the accessions with the highest seed weight per plant showed a lower 1000 seed weight.

The crude protein content in the four studied accessions of $A$. hypochondriacus seeds (17 to $18 \mathrm{~g} / 100 \mathrm{DM}$ ) is in agreement with the value reported by Rutkowska [51] (17.9\% $\mathrm{DM})$ and higher than the mean value $(15.6 \% \mathrm{DM}$, on average) observed by Barba de la Rosa et al. [35] in four varieties of A. hypochondriacus grown in Mexico. The crude protein content is also within the range reported in literature for amaranth seeds, which ranges from 13 to $18 \%$ [46,52-56]. Moreover, as a general rule, we could affirm that A. hypochondriacus exhibits a higher content of crude protein when compared to cereals such as corn $(10.3 \%$ of $\mathrm{DM})$, wheat (14\% DM), and rice (8.5\% DM) [54].

In the present study, the oil content ranges from 5 to $7 \%$ in the four different accessions of A. hypochondriacus according to data reported by Grobelnik Mlakar et al. [57] (6.1-7.3\%) in five observations of A. hypochondriacus and by Petkova et al. [58] in amaranth seeds with different origin, Indian (6.9\% DM) and Turkish (7.4\% DM). Barba de la Rosa et al. [35] and Rutkowska [51] found a lipid content within the range of 7.7-8.9\%, in different accession of A. hypochondriacus. Our data resulted also in agreement with the data found by Gresta et al. [31] in eight accessions of $A$. cruentus seeds (5.6-7.3\%, as fed). On the whole, as a general observation, $A$. hypochondriacus exhibits a higher oil content $(5.7 \% \mathrm{DM}$, on average) when compared to cereals such as corn $(4.5 \% \mathrm{DM})$, wheat $(2.1 \% \mathrm{DM})$, and rice $(2.1 \%$ DM) [54].

Ash content (3.3-3.5\%, mean value $3.4 \% \mathrm{DM})$ in the four A. hypochondriacus accessions is within the range recorded by Grobelnik Mlakar et al. [57] (3.3-3.4\%), but lower than the 
mean value (4.1\% DM) observed by Rutkowska [51]. Our values are also in agreement with those reported by Ogrodowska et al. in A. cruentus seeds [52]. Compared to other cereals, the ash content exhibits a higher content $(3.42 \% \mathrm{DM}$, on average) than corn $(1.4 \%$ $\mathrm{DM})$, wheat $(1.9 \% \mathrm{DM})$, and rice $(1.4 \% \mathrm{DM})[54]$.

Our results of crude fiber content (4.8-5.9\%) agree with the results obtained by Gobelin Mlakar et al. (4.9\%) [57] and are higher than that reported by Orona-Tamayo and ParedesLópez (2.2\%) [54]. Moreover, comparing the crude fiber content with that obtained in other Amaranthus spp., our data resulted lower than that reported by Pedersen et al. in $A$. caudatus grain (8.0\%) [55]. Finally, the crude fiber exhibits a higher content $(5.47 \% \mathrm{DM}$, on average) in comparison to cereals such as corn $(2.3 \% \mathrm{DM})$, wheat $(2.6 \% \mathrm{DM})$, and rice $(0.9 \%$ DM) [54].

In relation to the chemical composition of amaranth seeds, different studies were carried out on animal nutrition. Jalč et al. [36] in a feeding trial on sheep have demonstrated that $A$. hypochondriacus grain can represent a partial substitute of barley. Kubelková et al. [59] observed an increase of the microbial protein production in the effluents of ruminants fed with $A$. hypochondriacus grains. Moreover, amaranth can represent a valuable ingredient in the conventional rabbit feeding [21,60,61]. Reddy and Reddy [62] reported a favorable influence on growth in rabbits fed a ration containing A. hypochondriacus grain. Bamikole et al. [63] reported that unthreshed mature grain amaranth could be included in rabbit feeding up to a level of $10 \%$. Similar results were also obtained with other Amaranth spp.; Molina et al. [21] suggested that $A$. dubius could be used as a fiber and protein source for rabbit diets in subtropical and tropical regions. Moreover, Molina et al. [64] in rabbits fed with an increasing level of $A$. dubius, observed an increase in meat protein and fat contents. It has been also demonstrated that amaranth seeds, which have higher amount of protein than cereal grains and similar energy content, can be used as raw material in the finisher diets of broilers [65]. Waldroup et al. [38] showed that $A$. hypochondriacus, more than the $A$. cruentus grain, may be consumed by broiler chickens in substitution of the traditional control diet, based on maize-soybean meal. Kabuage et al. [23] observed that a pelleting of the amaranth in the diets of 8-week-old broiler chicks resulted in an increase of the body weight, feed intake, feed efficiency, and carcass fat.

Some unsaturated fatty acids, such as linoleic and linolenic acid, are exogenous acids essential for the animal body, playing an important role in regulating the immuneinflammatory system, hormone synthesis, cell membrane structure, and regulation of their permeability [66]. According to the literature [67], A. hypochondriacus exhibited a higher level of essential fatty acids, linoleic acid, and alpha-linolenic content than those reported by Gresta et al. [31] in eight accessions of $A$. cruentus ( $26.8 \%$ and $0.37 \%$, respectively). Consequently, also the total polyunsaturated fatty acids, both n6- and n3-PUFA, were higher in the A. hypochondriacus than those recorded by Gresta et al. [31] (27.19\%, 26.82\%, and $0.37 \%$, respectively).

Overall, our results suggest the possibility of replacing conventional cereals in pig feeding with the amaranth grains, owing to their relatively high dietary protein content and good dietary fiber content [68] and to their favorable lipid composition, in particular essential fatty acids which can be effective in the production of healthy pork as they modify the fatty acid composition of animal tissues [69].

As regards the nutritional aspects, in comparison with the main cereals used in animal feeding, the fatty acid composition of $A$. hypochondriacus showed a lower content of linoleic acid (omega 6) and linolenic acid (omega 3), and a higher content of oleic acid (omega 9) in comparison with maize (Zea mays) [70], wheat (Triticum aestivum and Triticum durum), barley (Hordeum vulgare), rye (Secale cereale), and triticale (Triticosecale) [71]. It must be mentioned that oleic acid has a beneficial effect on heart-diseases reducing the oxidation of LDL cholesterol, slowing the progression of atherosclerosis, and limiting cardiovascular risk [72,73]. The potential use of amaranth seeds in medicine to alleviate atherosclerotic disorders is well-known [32]. Our data evidenced a higher content of UFAs (63.13\% on average) than the SFAs (35\%) even if the SFA/UFA ratio appears significantly 
higher (0.56, on average) than that observed in literature on A. hypochondriacus grains by El Gendy et al. [5] (0.31), He et al. [67] (from 0.26 to 0.27), He et al. [74] (0.37), and Jahaniaval et al. [75] (from 0.37 to 0.40 ). Nevertheless, our data on the SFA/UFA ratio in the four studied accessions of $A$. hypochondriacus seeds appeared lower than that recorded by Gresta et al. [31] in A. cruentus grown in a Mediterranean environment (0.61, on average). Concerning the nutritional indices, there are no references in literature of the AI, TI, and $\mathrm{H} / \mathrm{H}$ indices in the oil from amaranth seeds except for the values reported by Gresta et al. [31] in eight accessions of $A$. cruentus which showed higher and, therefore, worse values than those recorded in our trial on A. hypochondriacus seeds. The atherogenic (AI) and thrombogenic (TI) indices applied by Ulbright and Southgate [33] indicate the relationship between the sum of three SFAs, lauric, myristic, and palmitic acids for AI and myristic, palmitic, and stearic acids for TI, and the sum of the main classes of unsaturated fatty acids, which are antiatherogenic. Therefore, AI is a measurement of the level of the atherogenicity while TI measures the level of thrombogenicity. A further beneficial effect of Amaranthus spp. on health can be ascribed to its hypocholesterolaemic action [8]. To evaluate the oil nutritional value, a further approach is represented by the ratio of the hypocholesterolaemic/hypercholesterolaemic fatty acids $(\mathrm{HH})$, calculated on the basis of the functional effects of individual fatty acids on the cholesterol metabolism [76]. Our data showed significant differences for $\mathrm{AI}, \mathrm{TI}$, and $\mathrm{H} / \mathrm{H}$ ratio among the accessions, resulting in the best values $(0.43,0.91,2.47$, respectively) in the accession from Nebraska for all the nutritional indices. Although A. hypochondriacus showed a low amount of n-3 PUFAs, the nutritional indices testify that the consumption of amaranth oil leads to improved cardiovascular health, decreases in bad cholesterol from blood, and helps to prevent metabolic imbalance [77]. Kabiri et al. [78,79] observed a significant reduction of the atherogenic index in atherosclerotic rabbits fed with amaranth extract supplementation. Plate and Arêas [80] demonstrated that the cholesterol-lowering effect of Amaranthus reduces low-density lipoprotein and total cholesterol levels in rabbit blood. Furthermore, Punita and Chaturvedi [26] fed laying hens with A. paniculatus grain and red palm oil, known to be a hypercholesteremic agent, and found an increase in the linoleic acid and a reduction in the cholesterol content in the eggs of hens fed red palm oil + amaranth and raw amaranth groups. Króliczewska et al. [81] studied the influence of 0, 2, 5, and $10 \%$ supplementation of $A$. cruentus grain on the biochemical and hematological blood parameter values of laying hens. The increase in inclusion level of amaranth determined a decrease in the low-density lipoprotein cholesterol.

In the four accessions of $A$. hypochondriacus seeds studied, the peroxidation index (PI) was significantly influenced by the accessions and showed an increase in relation to the increase in PUFA content, as observed by Gresta et al. [31] in A. cruentus grown in a Mediterranean environment. The PI average value reflected the different PUFA contents, being higher in our samples (34.4, on average) than that calculated by Gresta et al. [31] in $A$. cruentus seeds (27.6, on average). The peroxidation index (PI), that represents the relative rate of peroxidation reaction, showed the lowest content in accession from Pennsylvania.

Total polyphenol content in the four studied varieties of amaranth seed is in agreement with the data recorded by Akin-Idowu et al. [34] in five species of Amaranthus (A. caudatus, A. cruentus, A. hybrid, A. hypochondriacus and A. hybridus) and, specifically, with TPC content obtained on A. hypochondriacus ( $0.30 \mathrm{mg} \mathrm{GAE} / \mathrm{g}$ ) while it is higher than that observed by Gresta et al. [31] in eight accessions of $A$. cruentus (0.26. mg GAE/g, on average). When compared with other species, our values are much lower than those obtained in other pseudo-cereals like buckwheat (3.23 mg GAE/g) and quinoa ( $0.72 \mathrm{mg} \mathrm{GAE} / \mathrm{g})$, lower than those of corn $(0.49 \mathrm{mg} \mathrm{GAE} / \mathrm{g})$ and sesame $(0.42 \mathrm{mg} \mathrm{GAE} / \mathrm{g})$ and similar to those obtained in soybean (0.37 mg GAE/g), oatmeal (0.35 mg GAE/g), and linseed (0.31 mg GAE/g) [82], while they are higher than that recorded in oat $(0.20 \mathrm{mg}$ GAE /g) [83].

As regards, the scavenging activity ( $\mathrm{DPPH}^{\bullet}$ and $\left.\mathrm{ABTS}^{\bullet+}\right)$, the comparison with the results reported by literature must be very cautious since there are many assays for total antioxidant determination and each of them has its limitations [84]. In this study, we 
applied the capacity to scavenge the "stable" free radical 2,2 diphenyl-1-picrylhydrazyl $\left(\mathrm{DPPH}^{\bullet}\right)$ [47] and 2,2'-Azino-bis(3-ethylbenzothiazoline-6-sulfonic acid) diammonium salt radical cation $\left(\mathrm{ABTS}^{\bullet+}\right)$ frequently used to estimate the total antioxidant capacity of natural products, including crude extracts, polyphenols, phenolic acids, flavonoids, and others [85]. Results of the two assays confirmed the best antioxidant activity for the accession of Pennsylvania.

Comparing $\mathrm{DPPH}^{\bullet}$ to the data reported by Gresta et al. [31] in A. cruentus cultivated in the same environment where our trial was carried out, the range appears quite similar $(0.30-0.50 \mathrm{mg} / \mathrm{mL})$. Conversely, our $\mathrm{DPPH}^{\bullet}$ mean value is higher and that of $\mathrm{ABTS}^{\bullet+}$ is lower than those reported by Karamać et al. [10] (DPPH ${ }^{\bullet}: 0.21 \mathrm{mg} / \mathrm{mL} ; \mathrm{ABTS}^{\bullet+}: 7.62 \mu \mathrm{mol}$ $\mathrm{TE} / \mathrm{g}$ ), testifying a lower antiradical activity of A. hypochondriacus than that of $A$. caudatus seeds. Nevertheless, Peiretti demonstrated that amaranth seeds in the diet of rabbits could be used as an effective natural antioxidant supplement capable of protecting cellular membranes against oxidative damage [30]. Moreover, Longato et al. [86] observed a significant higher serum antioxidant power and a lower serum lipid peroxidation levels in broilers fed with diets containing 5 and $10 \%$ of amaranth grain than those receiving a diet without supplementation.

\section{Conclusions}

The productive traits of the four $A$. hypochondriacus accessions show valuable results that suggest that this species could be considered as a possible alternative crop to the traditional cereals for irrigated Mediterranean environment.

The chemical composition of the four accessions of A. hypochondriacus seed showed that this pseudo-cereal can be used to balance the animal diet. Protein and fat showed a higher content than the most important cereals. Moreover, not only the quantity, but also the lipid composition of $A$. hypochondriacus grains is appreciable for its nutritional value and its beneficial health properties. A. hypochondriacus seeds showed a high content of unsaturated fatty acid of the n6 (linoleic acid) and n9 (oleic acid) series, therefore, this seed oil can be used in animal nutrition to enrich the products of animal origin with fatty acids. Furthermore, A. hypochondriacus seed showed a higher total phenolic content than oat and a comparable content with soybean, oatmeal, and linseed, revealing that the use of amaranth grain can be considered as an effective natural antioxidant supplement in animal nutrition that helps protect cell and tissues from damaging effects of free radicals and oxidative stress.

Among amaranth accessions, Nebraska and Pennsylvania showed the highest oil content and emerged as the best healthy ingredient for animal feeding. In particular, the accession from Nebraska showed the highest levels of oleic and linoleic acids, the highest content of polyunsaturated fatty acids, the best atherogenic, thrombogenic indices, and hypocholesterolaemic/hypercholesterolaemic ratio, and the highest TPC content. The accession from Pennsylvania, showed the lowest peroxidation index and $\mathrm{DPPH}^{\bullet}$ value and, therefore, the highest antioxidant activity.

In this light, we can affirm that the choice of $A$. hypochondriacus seed as a substitute for traditional cereals, due to its potential source of health- promoting bioactive compounds, should be encouraged and different accessions could be chosen according to the different metabolic pathways of ruminants and monogastric animals.

Author Contributions: Conceptualization, F.G. and B.C.; methodology, F.G. and B.C.; software, F.G.; formal analysis, M.O., V.L.P., and A.C.; investigation, F.G.; data curation, F.G., B.C., G.M.; writingoriginal draft preparation, F.G., B.C., M.O.; writing-review and editing, F.G., B.C., M.O.; supervision, B.C. and F.G.; funding acquisition, B.C.. All authors have read and agreed to the published version of the manuscript.

Funding: This research was funded by PON-MISE I\&C 2014-2020 FESR, ASSE I-Innovazione e Azione, Azione 1.1.3. D.M. 05/03/2018, project codex N. F/200078/01-03/X45, CUP B41B20000280005, Title of the project "BIO=C=O", Scientific Responsible Biagina Chiofalo. 
Institutional Review Board Statement: Not applicable.

Informed Consent Statement: Not applicable.

Data Availability Statement: Not applicable.

Conflicts of Interest: The funders had no role in the design of the study; in the collection, analyses, or interpretation of data; in the writing of the manuscript, or in the decision to publish the results.

\section{References}

1. Cristaudo, A.; Gresta, F.; Luciani, F.; Restuccia, A. Effects of after-harvest period and environmental factors on seed dormancy of Amaranthus species. Weed Res. 2007, 47, 327-334. [CrossRef]

2. Cristaudo, A.; Gresta, F.; Catara, S.; Mingo, A. Assessment of daily heat pulse regimes on the germination of six Amaranthus species. Weed Res. 2014, 54, 366-376. [CrossRef]

3. Budin, J.T.; Breene, W.M.; Putnam, D.H. Some compositional properties of seeds and oils of eight Amaranthus species. J. Am. Oil Chem. Soc. 1996, 73, 475-481. [CrossRef]

4. Sánchez-López, F.; Robles-Olvera, V.J.; Hidalgo-Morales, M.; Tsopmo, A. Characterization of Amaranthus hypochondriacus seed protein fractions, and their antioxidant activity after hydrolysis with lactic acid bacteria. J. Cereal Sci. 2020, 95, 103075-103081. [CrossRef]

5. El Gendy, A.N.G.; Tavarini, S.; Conte, G.; Pistelli, L.; Hendawy, S.F.; Omer, E.A.; Angelini, L.G. Yield and qualitative characterisation of seeds of Amaranthus hypochondriacus L. and Amaranthus cruentus l. grown in central Italy. Ital. J. Agron. 2018, 13, 63-73. [CrossRef]

6. Marta, H.; Suryadi, E.; Ruswandi, D. Chemical Composition and Genetics of Indonesian Maize Hybrids. Am. J. Food Technol. 2017, 12, 116-123. [CrossRef]

7. Palavecino, P.M.; Penci, M.C.; Calderón-Domínguez, G.; Ribotta, P.D. Chemical composition and physical properties of sorghum flour prepared from different sorghum hybrids grown in Argentina. Starch-Staerke 2016, 68, 1055-1064. [CrossRef]

8. Iordanescu, I.P.; Popa, O.; Babeanu, N.; Nita, S.; Paraschiv, I.; Dobre, N.; Ionica, I. Physico-Chemical Characterization of Amaranth Extracts from Romanian Vegetal Sources with Antioxidant and Antiinflammatory Activities. Rev. Chim. 2015, 66, 634-636.

9. Tang, Y.; Tsao, R. Phytochemicals in quinoa and amaranth grains and their antioxidant, anti-inflammatory, and potential health beneficial effects: A review. Mol. Nutr. Food Res. 2017, 61, 1600767-1600782. [CrossRef]

10. Karamać, M.; Gai, F.; Longato, E.; Meineri, G.; Janiak, M.A.; Amarowicz, R.; Peiretti, P.G. Antioxidant Activity and Phenolic Composition of Amaranth (Amaranthus caudatus) during Plant Growth. Antioxidants 2019, 8, 173. [CrossRef]

11. Conforti, F.; Statti, G.; Loizzo, M.R.; Sacchetti, G.; Poli, F.; Menichini, F. In vitro antioxidant effect and inhibition of $\alpha$-amylase of two varieties of Amaranthus caudatus seeds. Biol. Pharm. Bull. 2005, 28, 1098-1102. [CrossRef]

12. Nsimba, R.Y.; Kikuzaki, H.; Konishi, Y. Antioxidant activity of various extracts and fractions of Chenopodium quinoa and Amaranthus spp. seeds. Food Chem. 2008, 106, 760-766. [CrossRef]

13. Peiretti, P.G.; Meineri, G.; Gai, F.; Longato, E.; Amarowicz, R. Antioxidative activity and phenolic compounds of pumpkin (Cucurbita pepo) seeds and amaranth (Amaranthus caudatus) grain extracts. Nat. Prod. Res. 2017, 31, 2178-2182. [CrossRef]

14. Asao, M.; Watanabe, K. Functional and bioactive properties of quinoa and amaranth. Food Sci. Technol. Res. 2010, 16, 163-168. [CrossRef]

15. Ogrodowskad, D.; Czaplicki, S.; Zadernowsli, R.; Mattila, P.; Hellström, J.; Naczk, M. Phenolic acids in seeds and products obtained from Amaranthus cruentus. J. Food Nutr. Res. 2012, 51, 96-101.

16. Ou, S.; Kwok, K.-Ch. Ferulic acid: Pharmaceutical functions, preparation and applications in food. J. Sci. Food Agric. 2004, 84, 1261-1269. [CrossRef]

17. Gawlik-Dziki, U. Fenolokwasy jako bioaktywne składniki żywności (Phenolic acids as bioactive food components). Żywność Nauka Technologia Jakość 2004, 41, 29-40.

18. Chitindingu, K.; Ndhlala, A.R.; Chapano, C.; Benhura, M.A.; Muchuweti, M. Phenolic compound content, profiles and antioxidant activities of Amaranthus hybridus (pigweed), Brachiaria brizantha (upright brachiaria) and Penicum maximum (guinea grass). J. Food Biochem. 2007, 31, 206-216. [CrossRef]

19. Alegbejo, J. Nutritional Value and Utilization of Amaranthus (Amaranthus spp.)—A Review. Bayero J. Pure Appl. Sci. 2014, 6, 136-143. [CrossRef]

20. Seguin, P.; Mustafa, A.F.; Donnelly, D.J.; Gélinas, B. Chemical composition and ruminal nutrient degradability of fresh and ensiled amaranth forage. J. Sci. Food Agric. 2013, 93, 3730-3736. [CrossRef] [PubMed]

21. Molina, E.; Redondo, G.P.; Rojas, M.R.; Quintero, M.K.; Bracho, B.; Urdaneta, S.A. Effects of diets with Amaranthus dubius Mart. ex Thell on performance and digestibility of growing rabbits. World Rabbit Sci. 2015, 23, 9-18. [CrossRef]

22. Sokól, J.L.; Bobel, B.K.; Fabijanska, M.; Bekta, M. Preliminary results on the influence of amaranthus seeds on carcass and meat quality of fatteners. J. Anim. Feed Sci. 2001, 10, 203-208. [CrossRef]

23. Kabuage, L.W.; Mbugua, P.N.; Mitaru, B.N.; Ngatia, T.A. Effect of Steam Pelleting and Inclusion of Molasses in Amaranth Diets on Broiler Chicken Performance, Carcass Composition and Histopathology of Some Internal Organs; AGRIPA, FAO electronic publishing; Polytechnic of Berlin: Berlin, Germany, 2002; pp. 1-10. Available online: http:/ / www.fao.org/docrep/ARTICLE/AGRIPPA/55 0_EN.HTM (accessed on 28 May 2021). 
24. Saunders, R.M.; Becker, R. Amaranthus: A Potential Food and Feed Resource. Adv. Cereal Sci. Technol. 1984, 6, 357-396.

25. Schnetzler, K.A.; Breene, W.M. Food uses and amaranth product research: A comprehensive review. In Amaranth Biology, Chemistry, and Technology; Peredes-López, O., Ed.; CRC Press: Boca Raton, FL, USA, 1994; pp. 155-184.

26. Punita, A.; Chaturvedi, A. Effect of feeding crude red palm oil (Elaeis guineensis) and grain amaranth (Amaranthus paniculatus) to hens on total lipids, cholesterol, PUFA levels and acceptability of eggs. Plant Foods Hum. Nutr. 2000, 55, 147-157. [CrossRef]

27. Roučková, J.; Trčková, M.; Herzig, I. The use of amaranth grain in diets for broiler chickens and its effect on performance and selected biochemical indicators. Czech J. Anim. Sci. 2004, 49, 532-541. [CrossRef]

28. Zralý, Z.; Písaříková, B.; Hudcová, H.; Trčková, M.; Herzig, I. Effect of feeding amaranth on growth efficiency and health of market pigs. Acta Vet. Brno 2004, 73, 437-444. [CrossRef]

29. Písaříková, B.; Zralý, Z.; Kráčmar, S.; Trčková, M.; Herzig, I. Nutritional value of amaranth (genus Amaranthus L.) grain in diets for broiler chickens. Czech J. Anim. Sci. 2005, 50, 568-573. [CrossRef]

30. Peiretti, P.G. Amaranth in animal nutrition: A review. Livestock Res. Rural Dev. 2018, 30, 1-20.

31. Gresta, F.; Meineri, G.; Oteri, M.; Santonoceto, C.; Lo Presti, V.; Costale, A.; Chiofalo, B. Productive and qualitative traits of amaranthus cruentus 1.: An unconventional healthy ingredient in animal feed. Animals 2020, 10, 1428. [CrossRef] [PubMed]

32. Skwaryło-Bednarz, B.; Stępniak, P.M.; Jamiołkowska, A.; Kopacki, M.; Krzepiłko, A.; Klikocka, H. Amaranth seeds as a source of nutrints and bioactive substances in human diet. Acta Sci. Pol. Hortorum Cultus 2020, 19, 153-164. [CrossRef]

33. Ulbricht, T.L.V.; Southgate, D.A.T. Coronary heart disease: Seven dietary factors. Lancet 1991, 338, 985-992. [CrossRef]

34. Akin-Idowu, P.E.; Ademoyegun, O.T.; Olagunju, Y.O.; Aduloju, A.O.; Adebo, U.G. Phytochemical Content and Antioxidant Activity of Five Grain Amaranth Species. Am. J. Food Sci. Technol. 2017, 5, 249-255.

35. de la Rosa, A.B.; Fomsgaard, I.S.; Laursen, B.; Mortensen, A.G.; Olvera-Martínez, L.; Silva-Sánchez, C.; Mendoza-Herrera, A.; González-Castañeda, J.; De León-Rodríguez, A. Amaranth (Amaranthus hypochondriacus) as an alternative crop for sustainable food production: Phenolic acids and flavonoids with potential impact on its nutraceutical quality. J. Cereal Sci. 2009, 49, 117-121. [CrossRef]

36. Jalč, D.; Baran, M.; Siroka, P. Use of grain amaranth (Amaranthus hypochondriacus) for feed and its effect on rumen fermentation in vitro. Czech J. Anim. Sci. 1999, 44, 163-167.

37. Ravindran, V.; Hood, R.L.; Gill, R.J.; Kneale, C.R.; Bryden, W.L. Nutritional evaluation of grain amaranth (Amaranthus hypochondriacus) in broiler diets. Anim. Feed Sci. Technol. 1996, 63, 323-331. [CrossRef]

38. Waldroup, P.W.; Hellwig, H.M.; Longer, D.E.; Endres, C.S. The utilization of grain amaranth by broiler chickens. Poult. Sci. J. 1985, 64, 759-762. [CrossRef]

39. Qureshi, A.A.; Lehmann, J.W.; Peterson, D.M. Amaranth and its oil inhibit cholesterol biosynthesis in 6-week-old female chickens. J. Nutr. 1996, 126, 1972-1978. [PubMed]

40. European Commission. Commission Regulation (EC) No 152/2009 of 27 January 2009 laying down the methods of sampling and analysis for the official control of feed (Text with EEA relevance). Off. J. Eur. Union 2009, 52, 12-15.

41. AOAC. Official Methods of Analysis, 21st ed.; Association of Official Analytical Chemists International: Gaithersburg, MD, USA, 2019.

42. European Commission. Commission Regulation (EC) No 152/2009 of 27 January 2009 laying down the methods of sampling and analysis for the official control of feed (Text with EEA relevance). Off. J. Eur. Union 2009, 52, 37-39.

43. Christie, W.W. Preparation of Ester Derivatives of Fatty Acids for Chromatographic Analysis. In Advances in Lipid Methodology-Two; Christie, W.W., Ed.; Oily Press: Dundee, Scotland, UK, 1993; pp. 69-111.

44. Santos-Silva, J.; Bessa, R.J.B.; Santos-Silva, F. Effect of genotype, feeding system and slaughter weight on the quality of light lambs. II. Fatty acid composition of meat. Livest. Prod. Sci. 2002, 77, 187-192. [CrossRef]

45. Luciano, G.; Pauselli, M.; Servili, M.; Mourvaki, E.; Serra, A.; Monahan, F.J.; Lanza, M.; Priolo, A.; Zinnai, A.; Mele, M. Dietary olive cake reduces the oxidation of lipids, including cholesterol, in lamb meat enriched in polyunsaturated fatty acids. Meat Sci. 2013, 93, 703-714. [CrossRef]

46. López-Mejía, O.A.; López-Malo, A.; Palou, E. Antioxidant capacity of extracts from amaranth (Amaranthus Hypochondriacus L.) seeds or leaves. Ind. Crops Prod. 2014, 53, 55-59. [CrossRef]

47. Brand-Williams, W.; Cuvelier, M.E.; Berset, C. Use of a free-radical method to evaluated antioxidant activity. LWT-Food Sci. Technol. 1995, 28, 25-30. [CrossRef]

48. Onofri, A. Routine statistical analyses of field experiments by using an excel extension. In Proceedings of the 6th National Conference Italian Biometric Society: La Statistica nelle Scienze della vita e Dell'ambiente, Pisa, Italy, 20-22 June 2007; pp. 93-99.

49. Pulvento, C.; Sellami, M.H.; Lavini, A. Yield and quality of Amaranthus hypochondriacus grain amaranth under drought and salinity at various phenological stages in southern Italy. J. Sci. Food Agric. 2021. [CrossRef] [PubMed]

50. Gimplinger, D.M.; Dobos, G.; Schönlechner, R.; Kaul, H.P. Yield and quality of grain amaranth (Amaranthus sp.) in Eastern Austria. Plant Soil Environ. 2007, 53, 105-112. [CrossRef]

51. Rutkowska, J. Amaranthus—roślina przyjazna człowiekowi [Amaranthus—A plant friendly to man]. Przeglad piekarski i cukierniczy 2006, 1, 6-10.

52. Ogrodowska, D.; Zadernowski, R.; Czaplicki, S.; Derewiaka, D.; Wronowska, B. Amaranth Seeds and Products-The Source of Bioactive Compounds. Pol. J. Food Nutr. Sci. 2014, 64, 165-170. [CrossRef] 
53. Gamel, T.H.; Linssen, J.P.; Mesallam, A.S.; Damir, A.A.; Shekib, L.A. Effect of seed treatments on the chemical composition and properties of two amaranth species: Starch and protein. J. Sci. Food Agric. 2005, 85, 319-327. [CrossRef]

54. Orona-Tamayo, D.; Paredes-López, O. Amaranth-Sustainable crop for the 21st century: Food Properties and nutraceuticals for improving human health. In Sustainable Protein Sources, 1st ed.; Nadathur, S., Wanasundara, J.P., Scanlin, L., Eds.; Elsevier Inc.: Aalborg, Denmark, 2017; pp. 239-256.

55. Pedersen, B.; Kalinowski, L.S.; Eggum, B.O. The nutritive value of amaranth grain (Amaranthus caudatus). Plant Food Hum. Nutr. 1987, 36, 309-324. [CrossRef]

56. Segura-Nieto, M.; Barba de la Rosa, A.P.; Paredes-López, O. Biochemistry of amaranth proteins. In Amaranth biology, Chemistry, and Technology; Paredes-Lopez, O., Ed.; CRC Press: Boca Raton, FL, USA, 1994; pp. 75-106.

57. Grobelnik Mlakar, S.; Turinek, M.; Jakop, M.; Bavec, M.; Bavec, F. Nutrition value and use of grain amaranth: Potential future application in bread making. Agricultura 2009, 6, 43-53.

58. Petkova, Z.Y.; Antova, G.A.; Angelova-Romova, M.I.; Vaseva, I.C. A comparative study on chemical and lipid composition of amaranth seeds with different origin. Bulg. Chem. Commun. 2019, 51, 262-267.

59. Kubelková, P.; Jalč, D.; Homolka, P.; Čermák, B. Effect of dietary supplementation with treated amaranth seeds on fermentation parameters in an artificial rumen. Czech J. Anim. Sci. 2013, 58, 159-166. [CrossRef]

60. Alfaro, M.A.; Ramírez, R.; Martínez, A.; Bressani, R. Evaluation of different amounts of amaranth meal (vegetative parts) to replace lucerne leaf meal in diets for growing rabbits. Arch. Latinoam. Nutr. 1987, 37, 174-185. [PubMed]

61. Bautista, E.; Barrueta, H.D.E. Bledo (Amaranthus spp.) como ingrediente en dietas para conejos en crecimiento y engorde. Revista Científica UNET 2000, 12, 1-17.

62. Reddy, K.J.; Reddy, M.B. Preliminary studies on Amaranthus (Amaranthus hypochondriacus) seed as a component of rabbit rations. Livestock Adviser. 1993, 18, 27-31.

63. Bamikole, M.A.; Ezenwa, I.; Adewumi, M.K.; Omojola, A.B.; Adetimirin, V.O.; Arigbede, O.M.; Orisadeyi, S.A. Alternative feed resources for formulating concentrate diets of rabbits. 1. Unthreshed grain amaranth seedhead. World Rabbit Sci. 2000, 8, 125-129. [CrossRef]

64. Molina, E.; González-Redondo, P.; Moreno-Rojas, R.; Montero-Quintero, K.; Sánchez-Urdaneta, A. Effect of the inclusion of Amaranthus dubius in diets on carcass characteristics and meat quality of fattening rabbits. J. Appl. Anim. Res. 2018, 46, 218-223. [CrossRef]

65. Peiretti, P.G.; Meineri, G.; Longato, E.; Tassone, S. Chemical composition, in vitro digestibility and fatty acid profile of Amaranthus caudatus herbage during its growth cycle. Anim. Nutr. Feed Technol. 2018, 18, 107-116. [CrossRef]

66. Januszewska-Jóźwiak, K.; Synowiecki, J. Charakte- rystyka i przydatność składników szarłatu w biotechno- logii żywności [Characteristics and suitability of amaranth components in food biotechnology]. Biotechnologia 2008, 3, 89-102.

67. He, H.; Cai, Y.; Sun, M.; Corke, H. Extraction and Purification of Squalene from Amaranthus Grain. J. Agric. Food Chem. 2002, 50, 368-372. [CrossRef]

68. Písaříková, B.; Kráčmar, S.; Herzig, I. Amino acid contents and biological value of protein in various amaranth species. Czech J. Anim. Sci. 2005, 50, 169-174. [CrossRef]

69. Zralý, Z.; Písaříková, B.; Trčková, M.; Herzig, I.; Jůzl, M.; Simeonovova, J. Effect of lupine and amaranth on growth efficiency, health, and carcass characteristics and meat quality of market pigs. Acta Vet. Brno 2006, 75, 363-372. [CrossRef]

70. Egesel, C.O.; Kahrıman, F.; Gül, M.K. Discrimination of maize inbreds for kernel quality traits and fatty acid composition by a multivariate technique. Acta Sci. Agron. 2011, 33, 613-620. [CrossRef]

71. Kan, A. Characterization of the Fatty Acid and Mineral Compositions of Selected Cereal Cultivars from Turkey. Rec. Nat. Prod. 2015, 9, 124-134.

72. Chiofalo, B.; Di Rosa, A.R.; Lo Presti, V.; Chiofalo, V.; Liotta, L. Effect of supplementation of herd diet with olive cake on the composition profile of milk and on the composition, quality and sensory profile of cheeses made therefrom. Animals 2020, 10, 977. [CrossRef] [PubMed]

73. Chiofalo, V.; Liotta, L.; Lo Presti, V.; Gresta, F.; Di Rosa, A.; Chiofalo, B. Effect of dietary olive cake supplementation on performance, carcass characteristics and meat quality of beef cattle. Animals 2020, 10, 1176. [CrossRef] [PubMed]

74. He, H.; Corke, H. Oil and Squalene in Amaranthus Grain and Leaf. J. Agric. Food Chem. 2003, 51, 7913-7920. [CrossRef] [PubMed]

75. Jahaniaval, F.; Kakuda, Y.; Marcone, M.F. Fatty acid and triacylglycerol compositions of seed oils of five Amaranthus accessions and their comparison to other oils. J. Am. Oil Chem. Soc. 2000, 77, 847-852. [CrossRef]

76. Dietschy, J.M. Dietary fatty acids and the regulation of plasma low density lipoprotein cholesterol concentrations. J. Nutr. 1998, 128, 444S-448S. [CrossRef]

77. Raiciu, A.D.; Popescu, M.; Ivopol, G.C.; Bordei, N.; Alexandru, G.; Crisan, I.; Manea, S.; Dima, S.O. Therapeutic applications of vegetable oils and GC-MS evaluation of $\omega-3, \omega-6$ and $\omega-9$ amounts in six oleaginous plants. Rev. Chim. 2016, 67, 2449-2453.

78. Kabiri, N.; Asgary, S.; Madani, H.; Mahzouni, P. Effects of Amaranthus caudatus L. extract and lovastatin on atherosclerosis in hypercholesterolemic rabbits. J. Med. Plant Res. 2010, 4, 355-364.

79. Kabiri, N.; Asgary, S.; Setorki, M. Lipid lowering by hydroalcoholic extracts of Amaranthus caudatus L. induces regression of rabbits atherosclerotic lesions. Lipids Health Dis. 2011, 10, 89-96. [CrossRef]

80. Plate, A.Y.A.; Arêas, J.A.G. Cholesterol-lowering effect of extruded amaranth (Amaranthus caudatus L.) in hypercholesterolemic rabbits. Food Chem. 2002, 76, 1-6. [CrossRef] 
81. Króliczewska, B.; Zawadzki, W.; Bartkowiak, A.; Skiba, T. The level of selected blood indicators of laying hens fed with addition of amaranth grain. Electron. J. Pol. Agric. Univ. 2008, 11, 18-22.

82. Camatari, F.O.S.; Lopes, K.H.; Valentim, B.; Xavier, J.A.; da Costa, J.G.; Santana, A.E.G.; Goulart, M.O.F. Antioxidant Potential of Flours from Cereals, Tubers, Beans and Seeds Chemical Profile of Curcuma longa Flour. J. Nutr. Food Sci. 2016, 6, 1-8.

83. Czerwinski, J.; Bartnikowska, E.; Leontowicz, H.; Lange, E.; Leontowicz, M.; Katrich, E. Oat (Avensa sativa L.) and amaranth (Amaranthus hypochondriacus) meals positively affect plasma lipid profile in rats fed cholesterol-containing diets. J. Nutr. Biochem. 2004, 15, 622-629. [CrossRef] [PubMed]

84. Ou, B.; Huang, D.; Hampsch-Woodill, M.; Flanagan, J.; Deemer, E. Analysis of antioxidant activities of common vegetables employing oxygen radical absorbance capacity (ORAC) and ferric reducing antioxidant power (FRAP) assays: A comparative study. J. Agric. Food Chem. 2002, 50, 3122-3128. [CrossRef]

85. Dong, J.-W.; Cai, L.; Xing, Y.; Yu, J.; Ding, Z.-T. Re-evaluation of ABTS ${ }^{\bullet+}$ Assay for Total Antioxidant Capacity of Natural Products. Nat. Prod. Commun. 2015, 10, 1934578X1501001239. [CrossRef]

86. Longato, E.; Meineri, G.; Peiretti, P.G. The effect of Amaranthus caudatus supplementation to diets containing linseed oil on oxidative status, blood serum metabolites, growth performance and meat quality characteristics in broilers. Anim. Sci. Pap. Rep. $2017,35,71-86$. 